\title{
Antitumor and anti-invasive effects of diverse musk-fragrant macrocyclic ketones and their enhancement by hyperthermia
}

\author{
RYOKO ASADA ${ }^{1}$, KATSUHIRO KAGEYAMA ${ }^{1}$, HIROSHI TANAKA ${ }^{1}$, \\ YASUKAZU SAITOH ${ }^{2}$ and NOBUHIKO MIWA ${ }^{2}$ \\ ${ }^{1}$ Osaka Butsuryo College, Nishi-ku, Sakai; ${ }^{2}$ Laboratory of Cell-Death Control BioTechnology, \\ Faculty of Life and Environmental Sciences, Prefectural University of Hiroshima, Shobara, Hiroshima, Japan
}

Received May 2, 2011; Accepted August 16, 2011

DOI: $10.3892 / \mathrm{mmr} .2011 .585$

\begin{abstract}
The antitumor and anti-invasive activities of the low-molecular-weight macrocyclic ketones (MCKs), such as musk secreted from the mammalian genital glands and musk released from relatively unkown plants, were investigated comparatively together with the enhancement of the effects in combination with hyperthermia. Ehrlich ascites tumor cells were treated with each MCK and cultured, followed by evaluation of the cell viability using the mitochondrial dehydrogenase-based WST- 8 assay. The number of HT-1080 human fibrosarcoma cells cultured with the MCKs or invading through a reconstituted basement membrane was measured using microscopy. The order of the efficiency was as follows: (Z)-g-cycloheptadecen-1-one (Hp) (17:1, musk rats), 8-cyclohexadecen-1-one (16:1, musk ferns), cyclopentadecanone (15:0, musk rats) and 3-methylcyclopentadecanone (16:0, musk deer), having 15-17 carbon atoms with and without a double bond, which exhibited a carcinostatic effect either at $100 \mu \mathrm{M}$ for 20 -h culture or at $50 \mu \mathrm{M}$ for 72 -h culture. The effects were markedly enhanced by heat treatment at $42^{\circ} \mathrm{C}$. MCKs were not found in the cells by gas-liquid chromatographic determination, indicating that the carcinostatic effects were attributed to their surface activity on the cell membrane. Invasion of HT-1080 cells was inhibited by MCKs at doses scarcely diminishing the cell viability, indicating that the suppression of invasiveness did not ensue from the secondary action due to carcinostasis. The order of invasion-inhibitory efficacy of the MCKs was, however, similar to that of their carcinostatic effects. Hp17:1 also exhibited the highest anti-invasive activity in addition to the highest carcinostatic activity. The two inhibitory effects were promoted by combination with hyperthermia. MCKs with a double bond, particularly Hp17:1 rather than 8-Hx16:1, but not saturated-aliphatic MCKs, may be potent multi-applicable antitumor agents due to their dual
\end{abstract}

Correspondence to: Dr Katsuhiro Kageyama, Osaka Butsuryo College, 3-33 Otorikita-cho, Nishi-ku, Sakai 593-8328, Japan

E-mail: kageyama@butsuryo.ac.jp

Key words: musk, macrocyclic ketones, antitumor activity, antiinvasive activity, hyperthermia inhibitory activities against tumor progression and invasion and in hyperthermia-combined therapy.

\section{Introduction}

The anti-cancer activity of natural macrocyclic lactones $(1,2)$ and delta-lactones isolated from plants or fungi $(3,4)$ have been reported. We extensively studied the activity of their synthesized compounds and previously reported the activity of the low-molecular-weight delta-alkyllactones and macrocyclic lactones $(5,6)$.

However, there have been few reports to date regarding the activities of MCKs similar to the lactone compounds $(7,8)$. These compounds have the highest molecular weights (approximately $1,060 \mathrm{Da}$ ) of the MCKs. With regard to the low-molecular-weight (224-250 Da) MCKs contained in musks secreted from the mammalian genital gland, these MCKs are quite chemically different from conventional substances. Their anti-tumor activity has yet to be elucidated.

In the present study, the carcinostatic activity of the MCKs was studied using Ehrlich ascites tumor (EAT) cells. The carcinostatic effects were evaluated by a decrease in mitochondrial dehydrogenase activity reflecting the survival rate of cells as measured using the WST- 8 assay $(9,10)$.

The ability of anti-tumor agents to inhibit tumor cell invasion into blood vessels prior to tumor metastasis is essential for clinical application. Anti-invasive activity of human fibrosarcoma (HT-1080) cells was revealed by diminished cell penetration through the reconstituted basement membrane (11).

Hyperthermia has received attention as an effective component of combined cancer treatments. Exposure of cultured tumor cells to temperatures above $41^{\circ} \mathrm{C}$ results in inhibition of DNA synthesis $(12,13)$ and tumor cell proliferation $(14,15)$. In the present study, in order to exceed the carcinostatic effect of MCKs alone, treatment with the MCKs was combined with hyperthermia. We studied whether the carcinostatic effect of MCKs on EAT cells was markedly enhanced by a combination treatment with hyperthermia. Furthermore, the relationship between the carcinostatic activity of the MCKs and the intracellular uptake determined by gas-liquid chromatography (GLC) $(6,16)$ was analyzed, and it was investigated whether hyperthermia increased the intracellular MCK accumulation. In this study, macrocyclic 
Table I. Macrocyclic ketones and their examined chemical structures.

\begin{tabular}{|c|c|c|c|c|}
\hline Chemical name & Abbreviation & Chemical formula & Chemical structure & Source \\
\hline Cyclopentadecanone & P15:0 & $\mathrm{C}_{15} \mathrm{H}_{28} \mathrm{O}$ & & Musk rat \\
\hline $\begin{array}{l}\text { 3-Methylcyclopentadecanone } \\
\text { (Muscone) }\end{array}$ & MP16:0 & $\mathrm{C}_{16} \mathrm{H}_{30} \mathrm{O}$ & & Musk deer \\
\hline $\begin{array}{l}\text { 8-Cyclohexadecen-1-one } \\
\text { (Animusk) }\end{array}$ & 8-Hx16:1 & $\mathrm{C}_{16} \mathrm{H}_{28} \mathrm{O}$ & & Musk fern \\
\hline $\begin{array}{l}\text { (Z)-g-Cycloheptadecen-1-one } \\
\text { (Civetone) }\end{array}$ & Hp17:1 & $\mathrm{C}_{17} \mathrm{H}_{30} \mathrm{O}$ & & Musk rat \\
\hline
\end{tabular}

ketones (MCKs) isolated from genital glands in animals or plants were found to be potent anti-cancer substances.

\section{Materials and methods}

Materials and cells. MCKs were kindly provided by Soda Aromatic Co., Ltd. (Tokyo, Japan). They were dissolved in ethanol and stored in a freezer as test solutions. They are shown in Table I. EAT cells (RCB: No. 0142) were purchased from the Institute of Physical and Chemical Research (Tsukuba, Japan). HT-1080 cells were obtained from Japanese Cancer Research Resources Bank (JCRB, Tokyo, Japan). These cells were cultured in minimum essential medium (MEM) (Gibco Labs Life Technologies, Inc., Grand Island, NY, USA) supplemented with $10 \%$ fetal bovine serum (FBS) (Gibco Labs Life Technologies).

Examination of carcinostatic effects and hyperthermic treatment. The examination of carcinostatic effects was conducted according to our developed system $(6,13)$. Briefly, cells were suspended in the culture medium at a density of $2 \times 10^{5}$ (culture for $20 \mathrm{~h}$ ) or $2 \times 10^{4}$ (culture for $72 \mathrm{~h}$ ) cells $/ \mathrm{ml}$. A $1-\mu \mathrm{l}$ aliquot of the test solution was transferred to a test tube. After the solvent was evaporated by jet flow of nitrogen gas, the culture medium was added to the residue (MCK) and sonicated to be homogenously emulsified. The suspension of cells and the test substance were mixed in a glass sample bottle $(14 \times 40 \mathrm{~mm})$. The cells were finally diluted with adjustment to a cell density of $1 \times 10^{5}$ or $1 \times 10^{4}$ cells $/ \mathrm{ml}$. The bottle was tightly covered with a plastic cap. The cell suspension was incubated at 37 or $42^{\circ} \mathrm{C}$ for $30 \mathrm{~min}$ in a water bath (Model BT-23, Yamato Scientific Co. Ltd, Tokyo, Japan) and maintained by sequential culture in a humidified atmosphere of $5 \% \mathrm{CO}_{2}$ in air at $37^{\circ} \mathrm{C}$ for $20 \mathrm{~h}$ or $72 \mathrm{~h}$. The cell viability was measured using the redox indicator dye WST-8 $(5,6)$ (Cell Counting WST-8 kit: Dojin Chemicals, Kumamoto, Japan). The assay solution became more chromic according to mitochondrial dehydrogenase activity. The cultured cell suspension was transferred to a sampling tube and was centrifuged. The supernatant was completely removed from the tube, $8 \%$ WST- 8 of $110 \mu \mathrm{l}$ was added to the cell precipitate, suspended and transferred to each well of a 96-well microplate. Following incubation at $37^{\circ} \mathrm{C}$ for $1 \mathrm{~h}$, the resultant diformazan formation was determined by measuring the absorption at $450 \mathrm{~nm}$ with a plate reader (Benchmark, Bio-Rad Laboratories, Hercules, CA, USA).

Tumor cell invasion assay. A quantity of $500 \mu \mathrm{l}$ of $10 \%$ FBS-MEM was added to each well of a 24-well culture plate, and then a Chemotaxicell invasion chamber (Kurabo Industries, Ltd., Osaka, Japan) with a porous resin membrane (8- $\mu \mathrm{m}$ diameter pores) precoated with Matrigel (Wako Pure Chemical Industries Ltd., Osaka, Japan) was inserted. Subsequently, $200 \mu \mathrm{l}\left(2 \times 10^{5}\right.$ cells $)$ of the above-mentioned suspension of HT- 1080 cells treated at 37 or $42^{\circ} \mathrm{C}$ for $1 \mathrm{~h}$ in the presence of the MCKs $(25 \mu \mathrm{M})$ was added, and the plate was incubated for $3 \mathrm{~h}$. Following incubation, the Chemotaxicell was removed, and after eliminating the supernatant and Matrix gel inside the Chemotaxicell, cells on the lower side of the resin membrane of the Chemotaxicell were fixed and stained using DifQuik (Green Cross, Osaka, Japan). The resin 


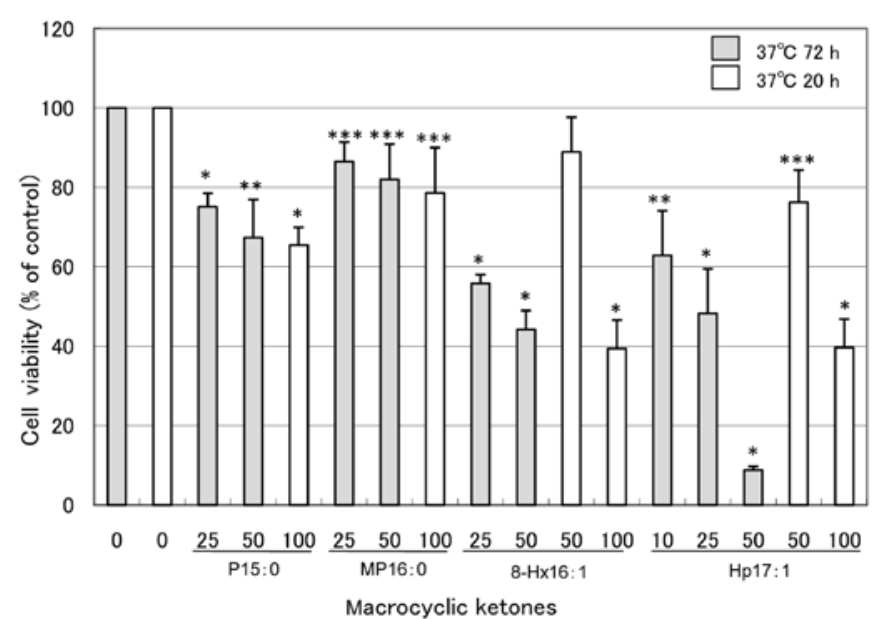

Figure 1. Short- and long-term carcinostatic effects of macrocyclic ketones (MCKs) on Ehrlich ascites tumor (EAT) cells as measured by mitochondrial dehydrogenase-based WST- 8 assay. Cells were seeded at a density of $1 \times 10^{5}$ (20-h cultures) or $1 \times 10^{4}$ (72-h cultures) cells/ml, incubated in the presence of each MCK at doses of $10-100 \mu \mathrm{M}$ at $37^{\circ} \mathrm{C}$ for $30 \mathrm{~min}$ and further maintained by sequential culture at $37^{\circ} \mathrm{C}$ for 20 or $72 \mathrm{~h}$. Viability of the cells was measured by the absorption at $450 \mathrm{~nm}$ in the WST- 8 assay. The absorbance of cells treated in the absence of MCKs at $37^{\circ} \mathrm{C}$ was $1.822 \pm 0.063$ or $2.08 \pm 0.02$ (the control value), respectively. Data shown represent the means \pm SEM for quadruplicate measurements as percentages of the control value Significantly different from the control: ${ }^{*} \mathrm{p}<0.0001,{ }^{* *} \mathrm{p}<0.001,{ }^{* * *} \mathrm{p}<0.05$.

membrane was then removed from the Chemotaxicell and fixed with the back surface on top in a slide glass. The number of stained cells was counted using microscopy $(5,11)$.

MCK accumulation in cells. Cells were suspended in culture medium and adjusted to a final cell density of $2 \times 10^{5}$ cells $/ \mathrm{ml}$. The MCKs were dispersed at a final concentration of $25 \mu \mathrm{M}$ by sonication. The cell suspension and DAL emulsion ( $7 \mathrm{ml}$ each) were mixed in a glass sample vial $(27 \times 65 \mathrm{~mm})$. The cells were finally adjusted to a cell density of $2 \times 10^{5}$ cells $/ \mathrm{ml}$. Cells were heated in a tightly stopped tube at 37 or $42^{\circ} \mathrm{C}$ controlled within $\pm 0.05^{\circ} \mathrm{C}$ for $30 \mathrm{~min}$ in a water bath (6). The bottles were then covered with glass caps. The heated suspension was incubated in a humidified atmosphere of $5 \% \mathrm{CO}_{2}$ in air at $37^{\circ} \mathrm{C}$ for $1 \mathrm{~h}$. The suspension was then centrifuged, and the supernatant was withdrawn with a pipette. The pellet (packed cells) was rinsed twice with $2 \mathrm{ml}$ of fresh culture medium, and homogenized for 1 min after removing as much supernatant as possible with a microliter syringe and adding $1 \mathrm{ml}$ chloroform. The mixture was poured into a glass tube $(5.5 \times 200 \mathrm{~mm})$ sealed with cotton, and the solvent was evaporated with a nitrogen gas stream. Chloroform was added to the residue (MCKs), and the sample (3 $\mu \mathrm{l})$ was analyzed with a gas chromatograph equipped with a flame ionization detector (GC-6AM; Shimadzu Seisakusho, Kyoto, Japan) and a column (2\% OV; $170.5 \mathrm{~m}$ in length) $(6,16)$.

Statistical analysis. Statistical differences were analyzed using the Student's t-test.

\section{Results}

Carcinostatic effects of MCKs on short-term (20 h) or longterm (72 h) cultures. Diverse species of MCKs were added to

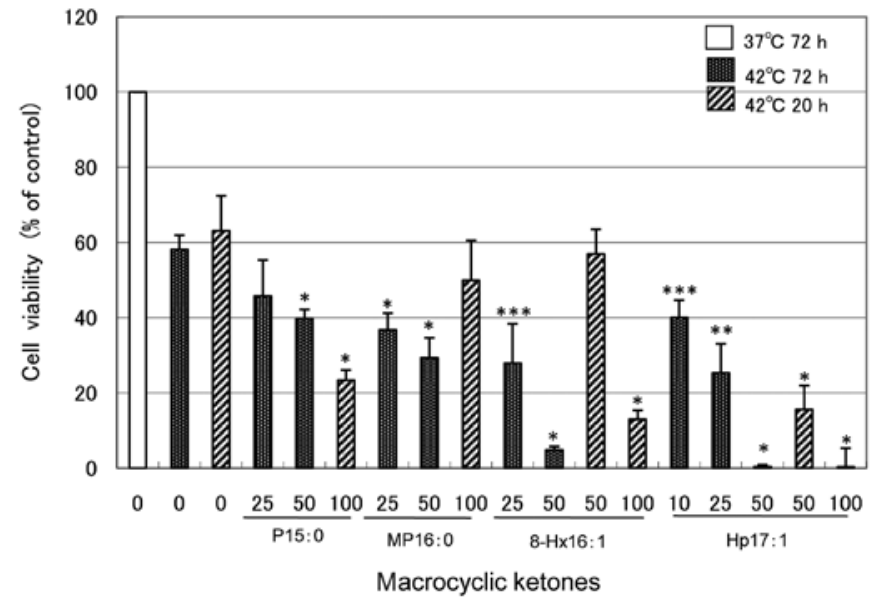

Figure 2. Short- and long-term carcinostatic effects of macrocyclic ketones (MCKs) on Ehrlich ascites tumor (EAT) cells in combination with hyperthermia (as measured by WST- 8 assay). Cells were seeded at a density of $1 \times 10^{5}$ (20-h cultures) or $1 \times 10^{4}$ (72-h cultures) cells $/ \mathrm{ml}$, incubated in the presence of each MCK at a dose of $10-100 \mu \mathrm{M}$ at $42^{\circ} \mathrm{C}$ for $30 \mathrm{~min}$ and further maintained by sequential culture at $37^{\circ} \mathrm{C}$ for 20 or $72 \mathrm{~h}$. Viability of the cells was measured by the absorption at $450 \mathrm{~nm}$ in the WST- 8 assay. The absorbances of cells treated in the absence of MCKs at $37^{\circ} \mathrm{C}$ for 20 and $72 \mathrm{~h}$ were $1.822 \pm 0.063$ and $2.08 \pm 0.02$ (the control values), respectively. Data shown represent the means \pm SEM of quadruplicate measurements as percentages of the control value. the EAT cells, the samples were heated in a water bath at $37^{\circ} \mathrm{C}$ for $30 \mathrm{~min}$ and were maintained by sequential culture at $37^{\circ} \mathrm{C}$ for 20 or $72 \mathrm{~h}$. The carcinostatic effects were measured using the WST-8 assay (Fig. 1). The cell viability of the control in the absence of MCK was observed to be $100 \%$. In the short-term culture period for $20 \mathrm{~h}, \mathrm{Hp17}: 1,8-\mathrm{Hx} 16: 1, \mathrm{P} 15: 0$, and MP16:0 at a dose of $100 \mu \mathrm{M}$ gave cell survival rates of $39.6 \pm 7.2 \% \quad(\mathrm{P}<0.0001), 39.4 \pm 7.2 \% \quad(\mathrm{P}<0.0001), 65.5 \pm 4.5 \%$ $(\mathrm{P}<0.0001)$ and $78.6 \pm 11.4(\mathrm{P}<0.030)$, respectively. In the long-term culture period for $72 \mathrm{~h}$, at a dose of $50 \mu \mathrm{M}$, these MCKs diminished the cell viability to $8.8 \pm 0.91 \%(\mathrm{P}<0.0001)$, $44.2 \pm 4.8 \%(\mathrm{P}<0.0001), 67.3 \pm 9.6 \%(\mathrm{P}<0.0003)$ and $82.0 \pm 8.9 \%$ $(\mathrm{P}<0.02)$, respectively, corresponding to the values at $100 \mu \mathrm{M}$ in the culture for $20 \mathrm{~h}$. Treatment with the most effective MCK, Hp17:1, even at a dose as low as $10 \mu \mathrm{M}$, decreased the cell viability to $62.9 \pm 11.2 \%(\mathrm{P}<0.0005)$.

Effect of hyperthermia on the carcinostatic effects of MCKs. Viability of the EAT cells cultured for 20 or $72 \mathrm{~h}$ after treatment at $42^{\circ} \mathrm{C}$ for $30 \mathrm{~min}$ was measured by the WST-8 assay (Fig. 2). The short-term culture period of $20 \mathrm{~h}$ after the hyperthermic treatment alone at $42^{\circ} \mathrm{C}$ diminished the viability to $63.1 \pm 12.0 \%(\mathrm{P}<0.0001)$ versus that of the control at $37^{\circ} \mathrm{C}$. The cell viabilities at a dose of $100 \mu \mathrm{M}$ MCK were in the following inverse order: Hp17:1 [0.4 $44.9 \%$ $(\mathrm{P}<0.0001)]>8-\mathrm{H} \times 16: 1 \quad[13.0 \pm 2.4 \% \quad(\mathrm{P}<0.0001)]>\mathrm{P} 15: 0$ $[23.4 \pm 2.7 \%(\mathrm{P}<0.0001)]>\mathrm{MP} 16: 0[49.9 \pm 10.6 \%(\mathrm{P}<0.1746)]$ indicating the carcinostatic effect exceeded that obtainable by hyperthermia alone. At a dose of $50 \mu \mathrm{M}$, only Hp17:1 reduced the cell viability to $15.6 \pm 6.4 \%(\mathrm{P}<0.0001)$ whereas the others were almost ineffective. In the long-term culture period for $72 \mathrm{~h}$ after the hyperthermic treatment, Hp17:1, 8-Hx16:1, MP16:0 and P15:0 reduced the viability of 


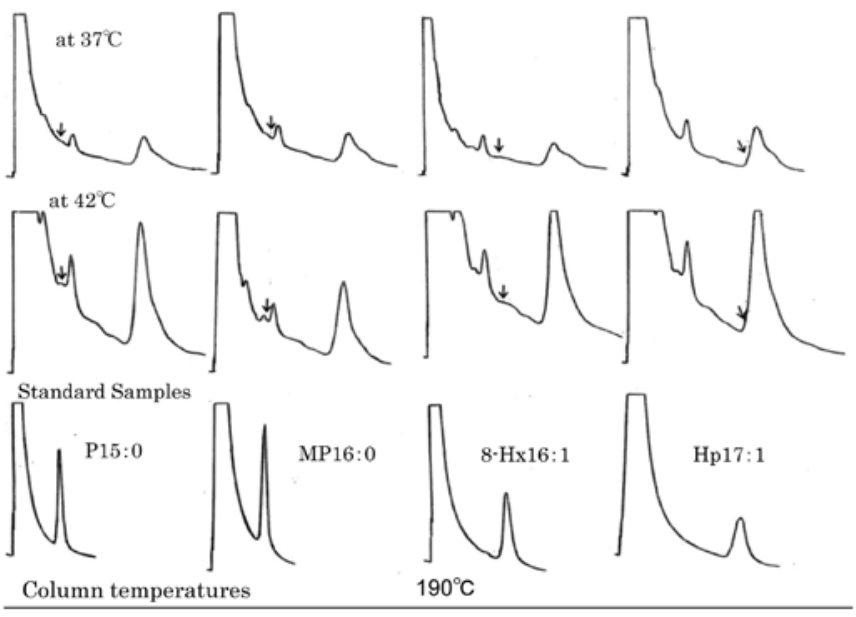

Retention time

Figure 3. Gas-liquid chromatograms of the samples extracted from Ehrlich ascites tumor cells treated with macrocyclic ketones (MCKs). Cells adjusted to a density of $2 \times 10^{5}$ cells $/ \mathrm{ml}$ were incubated in the presence of MCKs at a concentration of $25 \mu \mathrm{M}$ in a humidified atmosphere of $5 \% \mathrm{CO}_{2}$ in air at $37^{\circ} \mathrm{C}$ for $1 \mathrm{~h}$. The suspension was then centrifuged, and the supernatant was removed. The packed cells were rinsed with MEM and homogenized after removing as much of the supernatant as possible and adding $1 \mathrm{ml}$ of ethanol The homogenate was poured into a glass tube sealed with cotton, and the solvent of filtrates was evaporated. Ethanol was added to the residue (DAL), and the sample $(3 \mu 1)$ was analyzed with a gas chromatograph.

the cells to $0.4 \pm 0.5 \% \quad(\mathrm{P}<0.0001), 4.8 \pm 1.0 \% \quad(\mathrm{P}<0.0001)$, $29.3 \pm 5.3 \%(\mathrm{P}<0.0001)$ and $39.8 \pm 2.4 \%(\mathrm{P}<0.0001)$ at a dose of $50 \mu \mathrm{M}$ and were effective even at $25 \mu \mathrm{M}[25.3 \pm 7.8 \%$ $(\mathrm{P}<0.0001), 27.9 \pm 10.5 \%(\mathrm{P}<0.0035), 36.8 \pm 4.4 \%(\mathrm{P}<0.0001)$ and $45.7 \pm 9.6 \%(\mathrm{P}<0.1154)$ respectively]. The order of their carcinostatic activities was altered by combination with hyperthermia, with the exception ofHp17:1. It is clear that unsaturated MCKs such as 8-Hx16:1 and Hp17:1 were more effective than saturated MCKs such as P15:0 and MP16:0.

Intracellular accumulation of MCKs added to tumor cells. The more carcinostatic MCKs tend to be taken up and accumulated more abundantly in tumor cells (16). Accordingly the accumulation was measured in the cells subjected to treatment with MCKs (Fig. 3). Intracellular uptake of MCKs was not detected in all cells treated at 37 and $42^{\circ} \mathrm{C}$.

Effects of the MCKs on tumor cell invasion. The effects of the MCKs on tumor cell (HT-1080 cells) invasion are shown in Fig. 4. In the non-treated control sample, 137 out of all the cells $\left(2 \times 10^{5}\right)$ added passed through the porous resin membrane of the Chemotaxicell. Even for a short-term exposure $(3 \mathrm{~h})$ at a low MCK concentration of $25 \mu \mathrm{M}$, which did not exhibit any carcinostatic effect, tumor invasion was suppressed by all

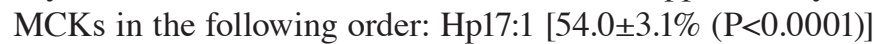
$>$ 8-Hx16:1 $[59.9 \pm 0.5 \% \quad(\mathrm{P}<0.0001)]>\mathrm{P} 15: 0 \quad[53.3 \pm 4.4 \%$ $(\mathrm{P}<0.0001)]>\mathrm{MP16}: 0[82.5 \pm 3.2 \%(\mathrm{P}<0.0001)]$ in view of an invasion-inhibitory intensity. The order of the intensity of the suppression of invasion for each MCK was similar to that of their carcinostatic activity. Unsaturated MCKs had a more marked inhibitory effect compared to saturated MCKs, and Hp17:1 exhibited the highest suppressive activity. At $42^{\circ} \mathrm{C}$, MCKs exhibited enhanced ability to suppress the invasive

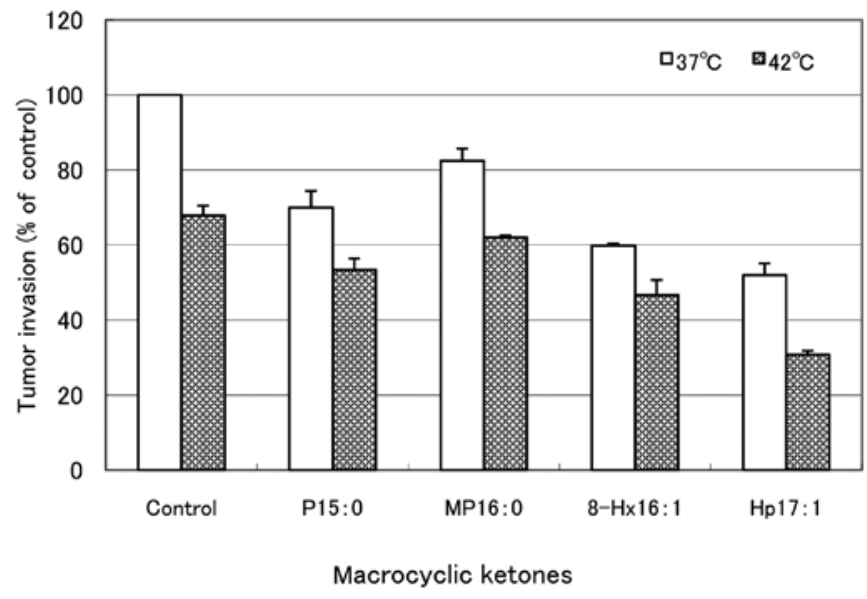

Figure 4. Inhibitory activity of macrocyclic ketones (MCKs) against the invasive activity of human fibrosarcoma HT-1080 cells. A total quantity of $200 \mu \mathrm{l}$ of 5 or $20 \mu \mathrm{M}$ of MCKs and HT-1080 cell suspension $\left(2 \times 10^{5}\right.$ cells) was placed onto a Chemotaxicell inserted onto a 24 -well plate and incubated for $1 \mathrm{~h}$. The cells that invaded through the reconstituted basement membrane were fixed and stained. The stained cells were counted using microsopy. Data shown are typical of three independent experiments that were conducted in triplicate; SD is represented by the bar.

activity of tumor cells. Hp17:1, 8-Hx16:1, P15:0 and MP16:0 reduced the invasive activity to $32.8 \pm 1.0 \% \quad(\mathrm{P}<0.0000)$, $43.8 \pm 2.0 \%(\mathrm{P}<0.0001), 62.0 \pm 0.58 \%(\mathrm{P}<0.0134)$ and $53.3 \pm 3.1 \%$ $(\mathrm{P}<0.0002)$ versus the control $(100 \%)$ at $37^{\circ} \mathrm{C}$, respectively and that of hyperthermia alone was $67.9 \pm 2.6 \%$.

\section{Discussion}

Macrocyclic ketones (MCKs), such as halichondrin B, have been previously reported as anti-tumor agents. These agents are extracted from sponges or marine organisms or synthesized chemically, and exert growth-inhibitory activities in vitro and in vivo against various types of human cancer cells $(7,8)$. Halichondrin B is an MCK of high molecular weight (approximately $1060 \mathrm{Da}$ ). In the present study, antitumor activity was first observed in musks secreted by the mammalian genital gland. These musks consist of MCKs of low molecular weight (224-250 Da). Carcinostatic activity was detected in diverse natural MCKs by the inhibition of mitochondrial dehydrogenase activity in Ehrlich ascites tumor cells and was markedly exhibited in the order: Hp17:1 > 8-Hx16:1 > P15:0 > MP16:0 (Figs. 1 and 2). The order in the degrees of carcinostatic activity was roughly consistent despite small changes due to differences in the bioassay methods such as treatment periods (20 or $72 \mathrm{~h}$ ) and treatment temperatures (37 and $42^{\circ} \mathrm{C}$ ). Unsaturated MCKs were more effective than saturated MCKs, and Hp17:1 exhibited the highest activity. The carcinostatic effects were markedly promoted by prolongation of culture periods (20 to $72 \mathrm{~h}$ ) or hyperthermia (37 to $42^{\circ} \mathrm{C}$ ). Hyperthermia increases superoxide anion radicals in cells, produces oxidative stress (17) and induces the inhibition of DNA synthesis $(12,13)$ and proliferation $(14,15)$.

As delta-alkyllactone penetrates the cell membrane, it appears to produce cytotoxic substances, including hydrogen peroxide and superoxide anions in the cells, resulting in carcinostasis (6). In contrast, macrocyclic lactones (MCLs) 
are not capable of penetrating the cell membrane, injure the membrane by their surface-activity, and bring about cytotoxic actions via the removal of microvilli and the deformation of cells, as morphologically observed using scanning electron microscopy (5).

To clarify whether the carcinostatic effect of MCKs was attributed to intracellular or extracellular injury, the examination of administered MCKs inside cells was carried out using GLC. Consequently, MCKs were not detected inside the cells and were not capable of penetrating the cell membrane. The carcinostasis induced by the MCKs were via the injury of the cell membrane in the same manner as the cytotoxic actions of MCLs (5).

Prevention of metastasis is a crucial subject. Inhibition of invasion of tumor cells using a blood vessel model in vitro is considered to reflect the prevention of permeation into the vein of cancer cells in the early stages of metastasis (11). MCKs inhibited the invasive action of human fibrosarcoma HT1080 cells even after the short-term exposure of $3 \mathrm{~h}$ at $25 \mu \mathrm{M}$, without reducing cell viability. The order of the suppressive intensity of invasiveness was similar to that of the carcinostatic activity. Accordingly, Hp17:1 exhibited the highest invasion-inhibitory activity and the highest carcinostatic activity. These effects were significantly promoted by hyperthermia.

In conclusion, certain MCKs, such as 8-Hx16:1 and, in particular, Hp17:1, are more attractive as potent anti-tumor regimens in terms of the absence of adverse side effects towards normal tissues and the lethal metastasis occurring secondarily after application of certain conventional cytotoxic anti-cancer agents.

\section{Acknowledgements}

We would like to thank Mr. Kunihiko Kinoshita, Managing Director, Dr Nobuhiko Ito, and Mr. Hiroshi Tsuji (Soda Aromatic Co., Ltd.) for their synthesis and supply of the macrocyclic ketone samples.

\section{References}

1. Pettit GR, Herald CL, Doubek DL, Herald DL, Arnold E and Clardy J: Isolation and structure of bryostatin-1. J Am Chem Soc 104: 6846-6848, 1982.

2. Iwasaki S, Kobayashi H, Furukawa J, Namikoshi M, Okuda S, Sato Z, Matsuda I and Noda T: Studies on macrocyclic lactone antibiotics. VII. Structure of a phytotoxin "Rhizoxin" produced by Rhizopus chinensis. J Antibiot 37: 354-362, 1984

3. Wani MC, Ronman PE, Lindley JT and Wall ME: Plant antitumor agents. 18. Synthesis and biological activity of camptothecin analogues. J Med Chem 23: 554-560, 1980.
4. Xu B and Ling YH: The effect of hydroxycamptothecin in the activity of RNA and DNA polymerases prepared from murine hepatoma cells. Am J Chinese Med 13: 23-31, 1985.

5. Tanaka H, Kageyama K, Kusumoto K, Asada R and Miwa N: Antitumor and anti-invasive effects of diverse new macrocyclic lactones, alkylolides and alkenylolides, and their enhancement by hyperthermia. Oncol Rep 18: 1257-1262, 2007.

6. Tanaka H, Kageyama K, Yoshimura N, Asada R, Kusumoto K and Miwa N: Anti-tumor and anti-invasive effects of diverse delta-alkyllactones: Dependence on molecular side-chain length, action period and intracellular uptake. Life Sci 80: 1851-1855, 2007.

7. Towle MJ, Salvato KA, Budrow J, Wels BF, Kuznetsov G, Aalfs KK, Welsh S, Zheng W, Seletsk BM, Palme MH, Habgood GJ, Singer LA, Dipietro LV, Wang Y, Chen JJ, Quincy DA, Davis A, Yoshimatsu K, Kishi Y, Yu MJ and Littlefield BA: In vitro and in vivo anticancer activities of synthetic macrocyclic ketone analogues of halichondrin B. Cancer Res 61: 1013-1021, 2001.

8. Zheng W, Seletsky BM, Palme MH, Lydon PJ, Singer LA, Chase CE, Lemelin CA, Shen Y, Davis H, Tremblay L, Towle MJ, Salvato KA, Wels BF, Aalfs KK, Kishi Y, Littlefield BA and Yu MJ: Macrocyclic ketone analogues of halichondrin B. Bioorg Med Chem Lett 14: 5551-5554, 2004.

9. Ishiyama M, Shiga M, Sakamoto K, Mizoguchi M and He PG: A new sulfonated tetrazolium salt that produces a highly watersoluble formazan dye. Chem Pharmaceut Bull 41: 1118-1122, 1993.

10. Kusumoto K, Kageyama K, Tanaka H, Kogawa H and Miwa N: Enhancement of carcinostatic activity of omega-hydroxy fatty acids by their esterification through increased uptake into tumor cells. Oncol Rep. 11: 857-861, 2004.

11. Albini A, Iwamoto Y, Kleinman HK, Martin GR, Aaronson A, Kozlowski JM and McEwan RN: A rapid in vitro assay for quantitating the invasive potential of tumor cells. Cancer Res 47: 3239-3245, 1987.

12. Mondvi B, Finzzi AA, Rotillo G, Strom R, Moricca G and Rossi FA: The biochemical mechanism of selective heat sensitivity of cancer cells. II. Studies on nucleic acids and protein synthesis. Eur J Cancer 5: 137-146, 1969.

13. Kageyama K, Onoyama Y, Nakanishi M, Matsui-Yuasa I, Otani S and Morisawa S: Synergistic inhibition of DNA synthesis in Ehrlich ascites tumor cells by a combination of unsaturated fatty acids and hyperthermia. J Appl Toxicol 9: 1-4, 1989.

14. Haris M: Criteria of viability in heat-treated cells. Exp Cell Res 44: 658-660, 1966.

15. Burattini S, Battistelli M, Luchetti F and Falcieri E: Effects of hyperthermia in human neuroblastoma cells. Ital J Anat Embryol 110 (2 Suppl 1): 49-53, 2005.

16. Kageyama K, Yamada R, Otani S, Onoyama Y, Yano I, Yamaguchi W, Yamaguchi Y, Kogawa H, Nagao N and Miwa N: Cytotoxicity of docosahexaenoic acid and eicosapentaenoic acid in tumor cells and the dependence on binding to serum proteins and incorporation into intracellular lipids. Oncol Rep 7: 79-83, 2000.

17. Cui Z, Wada S, Kondo T, Fujiwara Y, Zhao QL, Ogawa R, Nagaki Y, Shoji M, Tabuchi Y, Yuki H, and Feril LB Jr: Enhancement of hyperthermia-induced apoptosis by modification of intracellular oxidative stress. Jpn J Hyperthermic Oncol 21: 71-79, 2005. 